\title{
Protection of cultured human hepatocytes from hydrogen peroxide-induced apoptosis by relaxin-3
}

\author{
XIAO MA ${ }^{1}$, SU HAN ${ }^{2}$, WEI ZHANG ${ }^{3,4}$, YU-JING FAN ${ }^{1}$, MING-NA LIU ${ }^{1}$, AI-YUN LIU ${ }^{1}$ and BING-RONG LIU ${ }^{1}$ \\ ${ }^{1}$ Department of Gastroenterology and Hepatology, The Second Affiliated Hospital of Harbin Medical University; \\ ${ }^{2}$ Department of Microbiology and Parasitology, The Heilongjiang Key Laboratory of Immunity and Infection, \\ Pathogenic Biology, Harbin Medical University, Harbin, Heilongjiang 150086; ${ }^{3}$ Center for Endemic Disease Control, \\ Chinese Center for Disease Control and Prevention, Harbin Medical University; ${ }^{4}$ Key Lab of Etiology and Epidemiology, \\ Education Bureau of Hei Long Jiang Province and Ministry of Health, Harbin, Heilongjiang 150081, P.R. China
}

Received January 28, 2014; Accepted October 1, 2014

DOI: $10.3892 / \mathrm{mmr} .2014 .2842$

\begin{abstract}
Previous studies have suggested that hepatocyte apoptosis may be a fundamental underlying mechanism of liver injury and diseases, such as liver fibrosis. Relaxin-3 has been reported to have anti-fibrotic actions in the heart and to attenuate isoproterenol-induced myocardial injury; however, the beneficial role of relaxin-3 on hepatocyte apoptosis remains to be elucidated. The aim of the present study was to explore the role and possible mechanisms of relaxin-3 through hydrogen peroxide $\left(\mathrm{H}_{2} \mathrm{O}_{2}\right)$-induced apoptosis in primary human hepatocytes. Cells were treated with relaxin-3 and then cell viability, morphological features, the presence of cleaved caspases as well as the levels of endoplasmic reticulum stress (ERS) protein markers and autophagy markers were evaluated. The $\mathrm{H}_{2} \mathrm{O}_{2}$ group showed significantly decreased cell viability, increased apoptosis as well as upregulation of caspases (cleaved caspase-3, -8 and -9) and ERS protein markers compared with those of the control group. However, cells treated with relaxin-3 (10 $\mathrm{ng} / \mathrm{ml})$ demonstrated improved cell viability, reduced apoptosis and decreased expression of cleaved caspases and ERS markers. However, the expression of autophagy markers remained unchanged following $\mathrm{H}_{2} \mathrm{O}_{2}$-induced apoptosis and relaxin-3 treatment. In conclusion, relaxin-3 was shown to protect hepatocytes from $\mathrm{H}_{2} \mathrm{O}_{2}$-induced apoptosis via downregulation of cleaved caspase- 8 and -9 , as well as inhibition of the ERS pathway.
\end{abstract}

Correspondence to: Professor Bing-Rong Liu, Department of Gastroenterology and Hepatology, The Second Affiliated Hospital of Harbin Medical University, 246 Xue-Fu Road, Nan-Gang District, Harbin, Heilongjiang 150086, P.R. China

E-mail: mx_1983@yeah.net

Key words: relaxin-3, hepatocyte, apoptosis, endoplasmic reticulum stress, hydrogen peroxide

\section{Introduction}

Overproduction of reactive oxygen species (ROS), such as hydrogen peroxide $\left(\mathrm{H}_{2} \mathrm{O}_{2}\right)$, may induce pathological hepatocyte apoptosis (1). Oxidant-induced apoptosis has a pivotal role in the development and progression of liver diseases, including alcoholic liver diseases (2), drug-induced liver injury (3), viral hepatitis $(4,5)$, cholestatic liver diseases (6), non-alcoholic steatohepatitis (7) and ischemic/reperfusion injury, and also contributes to liver fibrogenesis (8). Therefore, the inhibition of hepatocyte apoptosis may be a promising novel therapeutic choice for the treatment of liver injury and fibrosis.

Apoptosis is initiated through two fundamental pathways: The extrinsic pathway, mediated by death receptors, and the intrinsic pathway, initiated by mitochondrial dysfunction (9). The cysteine aspartate protease (caspase) family of enzymes are key molecules whose activation may result in apoptosis; these include upstream initiator caspases (e.g. caspase- 8 and -9) and downstream effector caspases (e.g. caspase-3). In addition, ROS-induced endoplasmic reticulum stress (ERS) may initiate pathways which lead to caspase activation and apoptosis (10). The primary ERS-associated pathways are activated by endoplasmic reticulum (ER) membrane-associated proteins, including protein kinase R-like ER kinase (PERK), inositol-requiring enzyme 1 and activating transcription factor 6. Each of these pathways upregulates the transcription factor CCAAT-enhancer-binding protein homologous protein (CHOP), which results in decreased expression of anti-apoptotic B cell lymphoma (Bcl)-2 (11) and increased expression of pro-apoptotic Bcl-2 interacting mediator of cell death (12), therefore inducing apoptosis. The PERK pathway also activates caspase-12, which directly cleaves procaspase- 9 and then activates caspase-3, resulting in apoptosis (13).

Relaxin-3, first identified in 2002, is the ancestral peptide of the human relaxin subclass of the insulin superfamily (14). The primary site of relaxin-3 messenger (m)RNA expression is the brain; however, relaxin-3 is also present in other tissues, such as the liver (14). At present, the roles and mechanism of action of relaxin-3 remain to be fully elucidated; one study suggested that relaxin-3 was involved in brain functions, 
including the stress response and regulation of food intake, in combination with relaxin family peptide receptor 3 [RXFP-3/G protein-couple receptor (GPCR) 135] (15). In addition, relaxin-3 was also reported to bind to RXFP-1/leucine-rich repeat-containing GPCR 7 (LGR7; the primary receptor of relaxin-2) (16). In a previous study, LGR7 was expressed at a low level in normal rat livers; however, cirrhotic rat livers expressed significantly increased LGR7 levels in active hepatic stellate cells (17). Relaxin-3 treatment was reported to significantly increase the production of cyclic adenosine monophosphate, indicating the role of relaxin-3 in liver injury protection (18). Previous studies demonstrated that relaxin-2, in combination with LGR7, inhibited apoptosis in reproductive organ tissues during pregnancy (19) and in the heart (20). It was therefore hypothesized that relaxin-3 may attenuate hepatocyte apoptosis and protect against liver injury. The present study aimed to investigate the direct effect of relaxin-3 on hepatocyte apoptosis and its mechanism of action.

\section{Materials and methods}

Reagents. Synthetic human relaxin-3 was obtained from Phoenix Pharmaceuticals, Inc. (Burlingame, CA, USA). Rabbit anti-human CHOP polyclonal antibody as well as rabbit anti-human cleaved caspase 8 and 12 polyclonal antibodies were purchased from Abcam (Cambridge, UK). Rabbit anti-human Beclin 1 polyclonal antibody as well as rabbit anti-human cleaved caspase 9 and 3 antibodies were purchased from Cell Signaling Technologies, Inc. (Beverly, MA, USA). Rabbit anti-human microtubule associated protein 1 light chain 3 (LC3) polyclonal antibodies were purchased from Sigma (St. Louis, MO, USA). All chemicals and reagents used in this study were of analytical grade. The human normal liver cell line L02 was purchased from the cell bank of the Institute of Biochemistry and Cell Biology (Shanghai, China).

Hepatocyte culture and treatment. Human hepatocyte L02 cells were cultured at $37^{\circ} \mathrm{C}$ in an incubator $\left(5 \% \mathrm{CO}_{2}\right.$, 95\% air). RPMI-1640 medium (Hyclone, Inc., Logan, UT, USA) supplemented with $10 \%$ fetal bovine serum (Sijiqing, Inc., Huzhou, China) was used for the cell cultures. A dose-response experiment was initially conducted on the cells, which were treated with $0,20,50,100,200,400$, 600, 800 and 1,000 $\mu \mathrm{mol} / 1 \mathrm{H}_{2} \mathrm{O}_{2}$ (Sigma); $200 \mu \mathrm{mol} / 1$ was selected as the optimal dose for all subsequent experiments. At $\sim 70-80 \%$ confluence, cells were divided into the following five groups: Control; $\mathrm{H}_{2} \mathrm{O}_{2}, 200 \mu \mathrm{mol} / 1 \mathrm{H}_{2} \mathrm{O}_{2}$; R10, $200 \mu \mathrm{mol} / 1 \mathrm{H}_{2} \mathrm{O}_{2}+10 \mathrm{ng} / \mathrm{ml}$ relaxin-3; $\mathrm{R} 50,200 \mu \mathrm{mol} / 1 \mathrm{H}_{2} \mathrm{O}_{2}$ $+50 \mathrm{ng} / \mathrm{ml}$ relaxin-3; and $\mathrm{R} 100,200 \mu \mathrm{mol} / 1 \mathrm{H}_{2} \mathrm{O}_{2}+$ $100 \mathrm{ng} / \mathrm{ml}$ relaxin-3. Following co-incubation for $24 \mathrm{~h}$, cells from all five groups were collected for analysis.

Cell viability. Relative cell viability was determined using an MTT assay (Sigma). Cells were plated in 96-well microtiter plates (Corning, Inc., New York, NY, USA). Following cell treatment, MTT was added to the culture medium to yield a final MTT concentration of $0.5 \mathrm{mg} / \mathrm{ml}$; cells were then incubated for $4 \mathrm{~h}$ at $37^{\circ} \mathrm{C}$. The dye was dissolved by adding dimethyl sulfoxide at room temperature for $10 \mathrm{~min}$. The preparations were agitated thoroughly with the cells containing formazan crystals using a plate shaker. Absorbance was measured at $490 \mathrm{~nm}$ using a microplate reader (Bio-Rad, Inc., Hercules, CA, USA).

Hoechst staining. Apoptotic cells were characterized due to a distinctive condensed nuclear structure following staining with Hoechst 33258 (Beyotime, Inc., Haimen, China) and visible chromosomal fragmentation. Treated cells were fixed with $4 \%$ paraformaldehyde (Westang, Inc., Shanghai, China) for $15 \mathrm{~min}$ at room temperature, washed in phosphate-buffered saline (PBS) and then stained with Hoechst dye for $20 \mathrm{~min}$ at room temperature in the dark. Following washing with PBS, blue fluorescent cells were examined under a confocal scanning laser microscope (Nikon, Inc., Tokyo, Japan).

Transmission electron microscopy. Cells were harvested and fixed using $3.0 \%$ glutaraldehyde and $1.5 \%$ paraldehyde. Cells were then washed in PBS, fixed in osmium tetroxide (Xiya, Inc., Chengdu, China) and then dehydrated in an ethanol series. Subsequently, the samples were embedded in epoxy resin and examined under a transmission electron microscope (Olympus, Inc., Tokyo, Japan).

Western blot analysis. Following treatment for $24 \mathrm{~h}$, cells were washed with PBS and resuspended in cold lysis buffer containing phenylmethylsulfonyl fluoride. Cell lysates were incubated on ice for $30 \mathrm{~min}$ and then centrifuged at $12,000 \mathrm{xg}$ for $15 \mathrm{~min}$ at $4^{\circ} \mathrm{C}$. The protein content of the supernatant was determined using a bicinchoninic acid-200 protein assay kit (Beyotime, Inc.). Equal amounts of protein $(20 \mu \mathrm{g})$ from each group were separated using 12\% SDS-PAGE (Sanland, Inc., Xiamen, China) and transferred onto poly vinylidene difluoride (PVDF) membranes (Gelman, Inc., Morgan Hill, CA, USA). The membranes were blocked using 5\% skimmed milk (Yili, Inc., Neimenggu, China) for $1 \mathrm{~h}$ at room temperature with agitation and then incubated with the corresponding primary antibodies overnight at $4^{\circ} \mathrm{C}$. All of the following primary antibodies were diluted in Tris-buffered saline/Tween 20 (TBST) solution (anti- $\beta$-actin, 1:2,000; anti-CHOP, 1:500; anti-cleaved caspase-12, 1:500; anti-cleaved caspase-8, 1:1,000; anti-cleaved caspase-9, 1:1,000; anti-cleaved caspase-3, 1:1,000; anti-Beclin-1, 1:1,000; and anti-LC3, $1: 1,000)$. Samples were then washed three times (10 $\mathrm{min} / \mathrm{wash})$ with TBST and a secondary antibody $(1: 2,000)$ conjugated with alkaline phosphatase (ZSGB-BIO, Inc., Beijing, China) was added to the membranes, which were then incubated at room temperature for $1 \mathrm{~h}$ with agitation. The membranes were then washed three times (10 $\mathrm{min} /$ wash) prior to visualization using Western Blue ${ }^{\circledR}$ stabilized substrate for alkaline phosphatase (Promega Corp., Madison, WI, USA). In order to quantify the band intensities, the western blot membranes were scanned using ImageJ software (National Institute of Health, Bethesda, MA, USA). The results were normalized based on the respective levels of $\beta$-actin.

Statistical analysis. GraphPad Prism software version 5.0 (La Jolla, CA, USA) was used for data analysis. Each experiment was repeated a minimum of three times and 

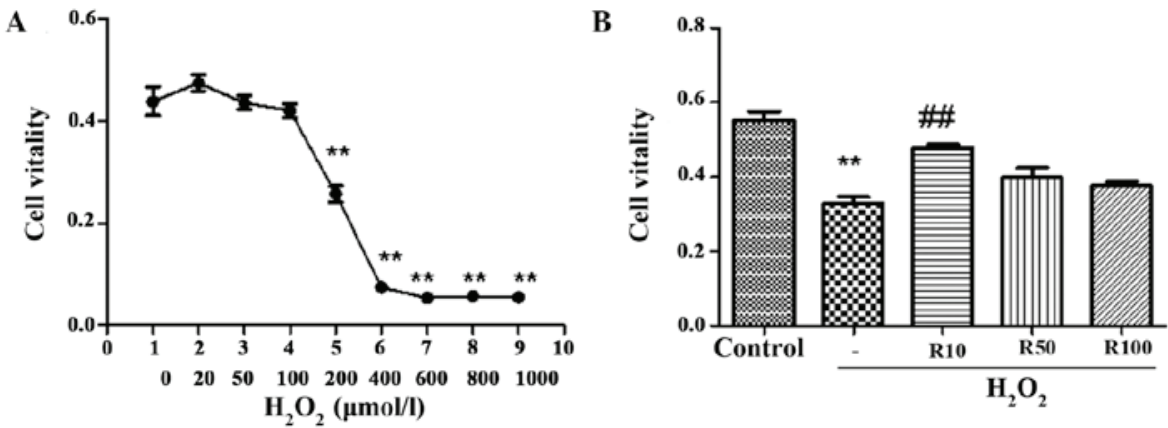

Figure 1. Relaxin-3 improves $\mathrm{H}_{2} \mathrm{O}_{2}$-induced decreased hepatocyte viability. (A) An MTT assay demonstrated the dose-dependent decrease in hepatocyte viability following treatment with concentrations of $\mathrm{H}_{2} \mathrm{O}_{2}$ for $24 \mathrm{~h}$. (B) Hepatocyte viability following $\mathrm{H}_{2} \mathrm{O}_{2}$-induced apoptosis alone or in combination with relaxin-3 treatment (R10, R50 and R100) for $24 \mathrm{~h}$. Values are expressed as the mean \pm standard deviation $(\mathrm{n}=6) .{ }^{* *} \mathrm{P}<0.01$ vs. control, ${ }^{\# \#} \mathrm{P}<0.01 \mathrm{vs} . \mathrm{H}_{2} \mathrm{O}_{2}$. $\mathrm{H}_{2} \mathrm{O}_{2}$, hydrogen peroxide-treatment; R10/50/100, treatment with 10,50 or $100 \mathrm{ng} / \mathrm{ml}$ relaxin-3, respectively.

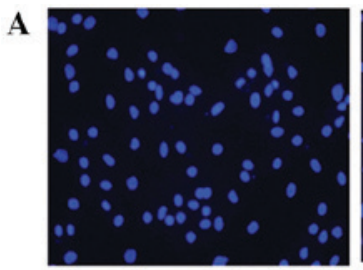

Control

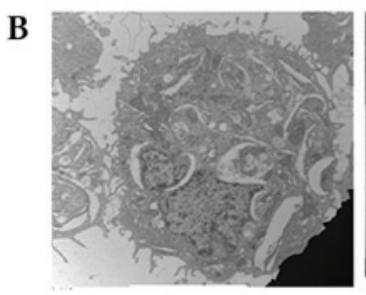

Control

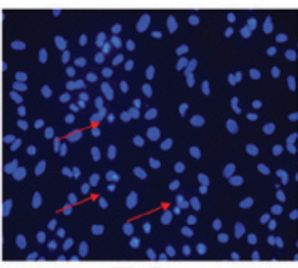

$\mathrm{H}_{2} \mathrm{O}_{2}$

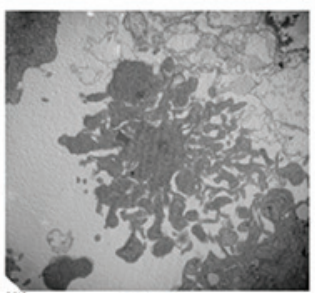

$\mathbf{H}_{2} \mathbf{O}_{2}$

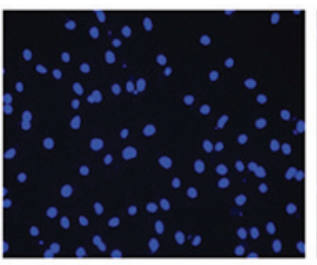

$\mathbf{H}_{2} \mathbf{O}_{2}+\mathbf{R} 10$

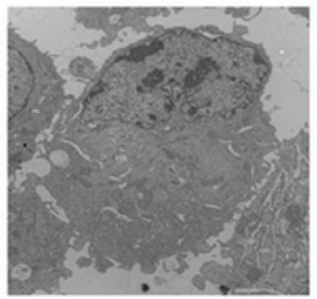

$\mathrm{H}_{2} \mathrm{O}_{2}+\mathrm{R} 10$

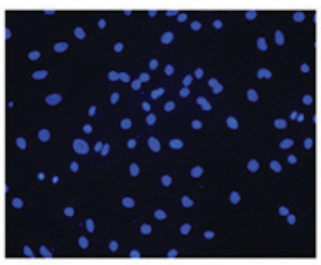

$\mathrm{H}_{2} \mathbf{O}_{2}+\mathbf{R 5 0}$

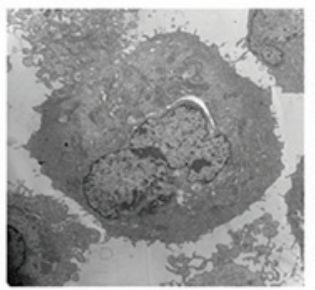

$\mathrm{H}_{2} \mathrm{O}_{2}+\mathbf{R 5 0}$

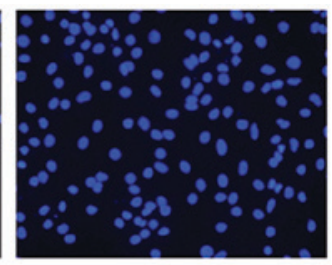

$\mathrm{H}_{2} \mathrm{O}_{2}+\mathbf{R} 100$

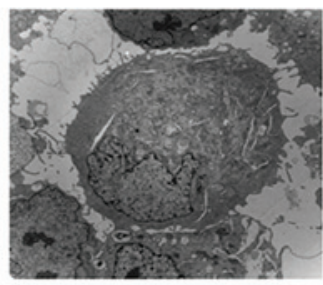

$\mathrm{H}_{2} \mathrm{O}_{2}+\mathbf{R} 100$

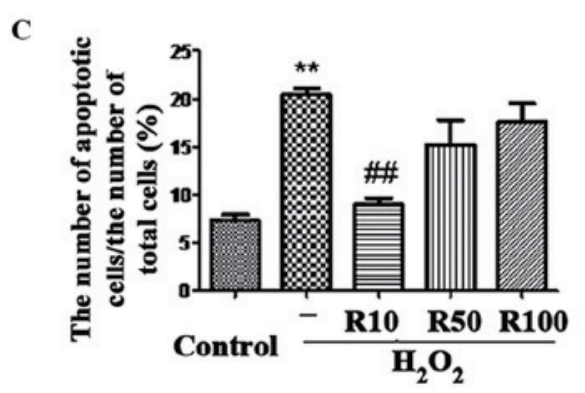

D
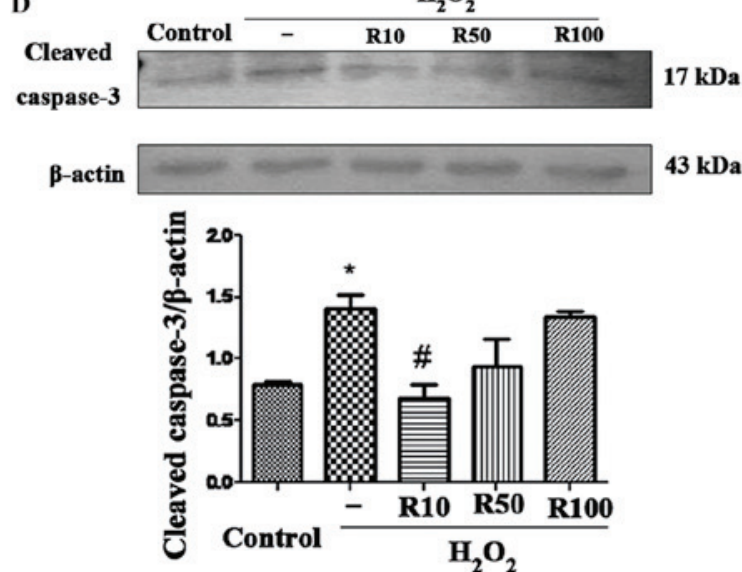

Figure 2. Relaxin-3 inhibits $\mathrm{H}_{2} \mathrm{O}_{2}$-induced hepatocyte apoptosis. (A) Hoechst staining reveals condensed and fragmented apoptotic nuclei of hepatocytes in the control, $\mathrm{H}_{2} \mathrm{O}_{2}$ or relaxin-3-treated (R10, R50 and R100 for $24 \mathrm{~h}$ ) groups. Arrows indicate condensed nuclei (magnification, x100; n=5). (B) Transmission electron microscopy of hepatocyte apoptosis in each group (magnification, x10,000). (C) Quantification of the percentage of apoptotic cells counted in each group. (D) Western blot analysis and quantification of cleaved caspase-3 protein levels in each group. $\beta$-actin was used as the internal control. Values are presented as the mean \pm standard deviation $(\mathrm{n}=3)$. ${ }^{*} \mathrm{P}<0.05$ vs. control, ${ }^{* *} \mathrm{P}<0.01$ vs. control, ${ }^{\#} \mathrm{P}<0.05$ vs. $\mathrm{H}_{2} \mathrm{O}_{2},{ }^{\# \#} \mathrm{P}<0.01$ vs. $\mathrm{H}_{2} \mathrm{O}_{2}$. $\mathrm{H}_{2} \mathrm{O}_{2}$, hydrogen peroxide treatment; R10/50/100, treatment with 10,50 or $100 \mathrm{ng} / \mathrm{ml}$ relaxin-3, respectively.

values are expressed as the mean \pm standard deviation. The one-way analysis of variance followed by the Newman-Keuls multiple comparison test were used for comparisons among the five groups. $\mathrm{P}<0.05$ was considered to indicate a statistically significant difference between values.

\section{Results}

Relaxin-3 attenuates $\mathrm{H}_{2} \mathrm{O}_{2}$-induced hepatocyte apoptosis. Cell viability assays, Hoechst staining, electron microscopy and western blot analysis were used in order to determine the 

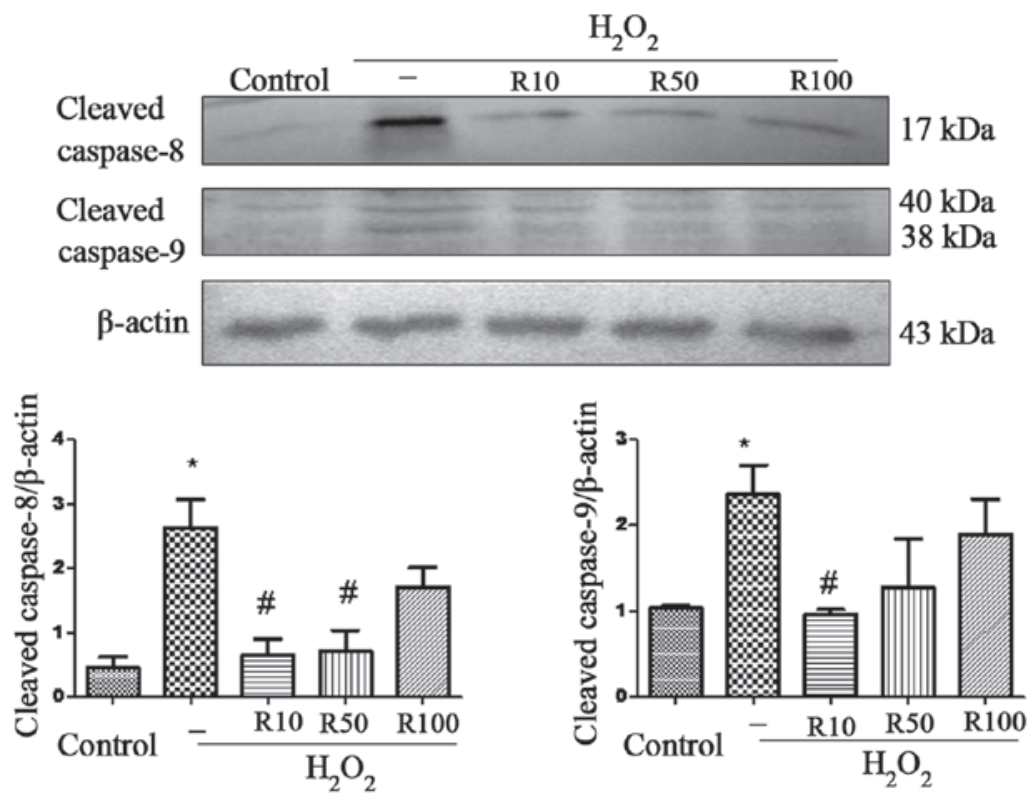

Figure 3. Relaxin-3 inhibits $\mathrm{H}_{2} \mathrm{O}_{2}$-induced hepatocyte apoptosis via suppression of cleaved caspase- 8 and -9 expression. Western blot analyses of cleaved caspase- 8 and -9 protein expression in hepatocytes of the control, $\mathrm{H}_{2} \mathrm{O}_{2}$ or relaxin-3-treated (R10, R50 and R100 for $24 \mathrm{~h}$ ) groups. $\beta$-actin was used as the internal control. Values are presented as the mean \pm standard deviation $(\mathrm{n}=3)$. ${ }^{*} \mathrm{P}<0.05$ vs. control, ${ }^{"} \mathrm{P}<0.05$ vs. $\mathrm{H}_{2} \mathrm{O}_{2} . \mathrm{H}_{2} \mathrm{O}_{2}$, hydrogen peroxide treatment; R10/50/100, treatment with 10,50 or $100 \mathrm{ng} / \mathrm{ml}$ relaxin-3, respectively.

effect of treatment with graded concentrations of relaxin-3 on $\mathrm{H}_{2} \mathrm{O}_{2}$-induced hepatocyte apoptosis.

As shown in Fig. 1A, exposure of human hepatocytes to graded concentrations of $\mathrm{H}_{2} \mathrm{O}_{2}(0-1,000 \mu \mathrm{mol} / \mathrm{l})$ for $24 \mathrm{~h}$ remarkably decreased cell viability in a dose-dependent manner. Concentrations of $\mathrm{H}_{2} \mathrm{O}_{2}$ produced significant results at $200 \mu \mathrm{mol} / 1$ and reached maximum inhibition between 400-600 $\mu \mathrm{mol}$. Administration of $10 \mathrm{ng} / \mathrm{ml}$ relaxin-3 to cells treated with $200 \mu \mathrm{mol} \mathrm{H}_{2} \mathrm{O}_{2}$ was found to significantly enhance cell viability; however, the protective effect of relaxin-3 diminished at higher doses (Fig. 1B).

Nuclear condensation, a hallmark characteristic of apoptotic cells, was observed in cells in the $\mathrm{H}_{2} \mathrm{O}_{2}$ only group following Hoechst staining. By contrast, cells treated with relaxin-3 were round and homogeneous, with a markedly decreased number of apoptotic nuclei, most notably in the R10 group (Fig. 2A). Cell morphological changes were also observed using electron microscopy (Fig. 2B). The later stages of apoptosis are characterized by nuclear pyknosis, mitochondrial and endoplasmic reticulum distension, as well as the formation of apoptotic bodies. These characteristics of later stage apoptosis were observed in cells in the $\mathrm{H}_{2} \mathrm{O}_{2}$ group; however, no obvious apoptotic changes were detected in the relaxin-3 treated cells. Quantification of the percentage of apoptotic cells counted in each group by Hoechst staining is shown in Fig. 2C. The results demonstrated that $\mathrm{H}_{2} \mathrm{O}_{2}$ treatment significantly increased the number of apoptotic cells compared with that of the control. By contrast, the R10 relaxin-3 treatment group $(10 \mathrm{ng} / \mathrm{ml})$ showed a significantly decreased number of apoptotic cells compared with that of the $\mathrm{H}_{2} \mathrm{O}_{2}$ group $(\mathrm{P}<0.05)$; however, the decrease in the number of apoptotic cells in the R50 and R100 treatment groups were not significant compared with levels in the $\mathrm{H}_{2} \mathrm{O}_{2}$ group (Fig. 2C).

Intrinsic and extrinsic apoptotic pathways activate the proenzyme form of caspase-3, which is then cleaved through self-proteolysis and other proteases (21). Therefore, endogenous cleaved (activated) caspase- 3 is a common indicator of cellular apoptosis. In the present study, western blot analysis was used to determine the expression levels of cleaved caspase-3. The results demonstrated that $\mathrm{H}_{2} \mathrm{O}_{2}$ treatment significantly increased the expression of cleaved caspase- 3 compared to that of the control. By contrast, the relaxin-3 R10 treatment group (10 $\mathrm{ng} / \mathrm{ml})$ showed significantly attenuated cleaved caspase-3 protein levels compared to those of the $\mathrm{H}_{2} \mathrm{O}_{2}$ group $(\mathrm{P}<0.05)$; however, the decrease in caspase- 3 protein levels in the R50 and R100 treatment groups was not significant compared to levels in the $\mathrm{H}_{2} \mathrm{O}_{2}$ group (Fig. 2D).

Relaxin-3 attenuates the $\mathrm{H}_{2} \mathrm{O}_{2}$-induced increase in cleaved caspase- 8 and -9 levels. Caspase- 8 and -9 are upstream mediators of the extrinsic and intrinsic apoptotic pathways, respectively; cleavage of these caspases results in the activation of downstream executioner caspases, such as caspase-3 (21). Therefore, in the present study, western blot analysis was used to determine the levels of cleaved caspase- 8 and -9 using western blot anlaysis and investigate whether these pathways were involved in the anti-apoptotic effect of relaxin-3 (Fig. 3). The results revealed that the protein expression of cleaved caspase- 8 and -9 was significantly increased in the $\mathrm{H}_{2} \mathrm{O}_{2}$ group compared to that of the control group. However, the R10 and R50 relaxin-3 treatment groups demonstrated significantly attenuated cleaved caspase- 8 levels compared to those of the $\mathrm{H}_{2} \mathrm{O}_{2}$ group; in addition, cleaved caspase- 9 protein expression was significantly reduced in the $\mathrm{R} 10$ group $(\mathrm{P}<0.05)$.

Relaxin-3 inhibits $\mathrm{H}_{2} \mathrm{O}_{2}$-induced ERS. Sustained or severe ERS leads to apoptosis through several pathways, including the CHOP and caspase-12 pathways (22). Therefore, the present study used western blot analysis to detect protein 

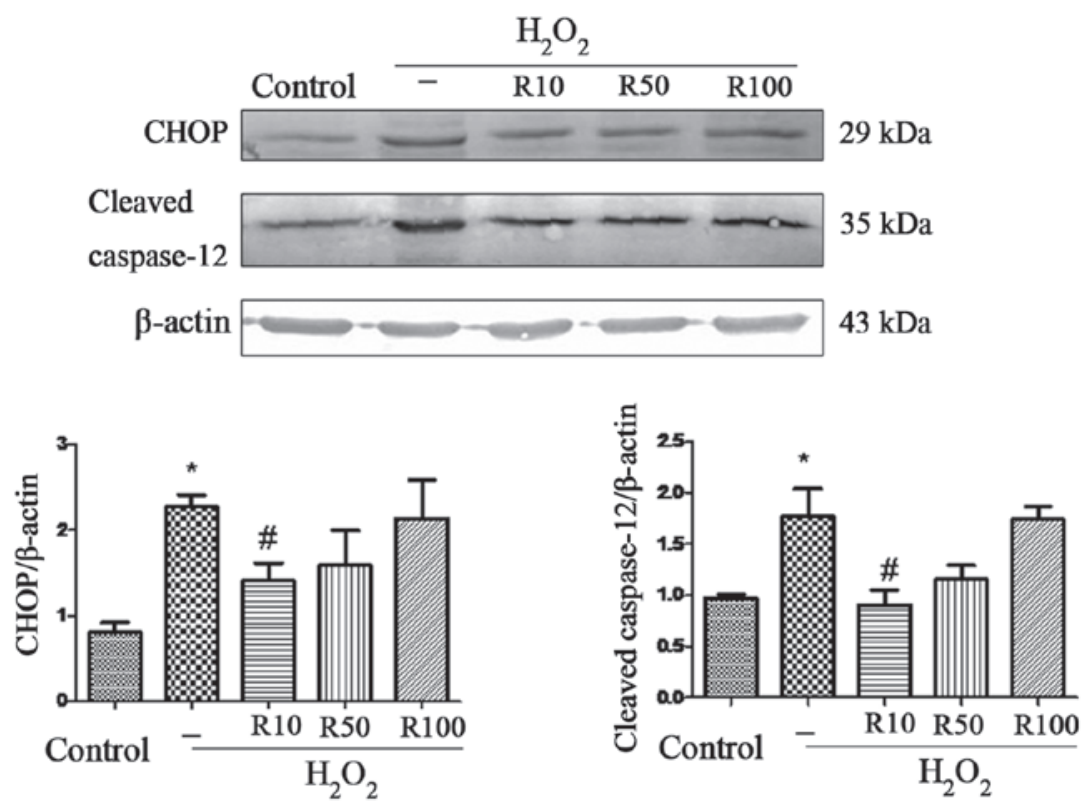

Figure 4. Relaxin-3 inhibits $\mathrm{H}_{2} \mathrm{O}_{2}$-induced hepatocyte apoptosis via suppressing endoplasmic reticular stress. Western blot analyses of CHOP and cleaved caspase-12 protein expression in hepatocytes of the control, $\mathrm{H}_{2} \mathrm{O}_{2}$ or relaxin-3-treated (R10, R50 and R100 for 24 h) groups. $\beta$-actin was used as the internal control. Values are presented as the mean \pm standard deviation $(n=3)$. ${ }^{*} \mathrm{P}<0.05$ vs. control, ${ }^{\#} \mathrm{P}<0.05$ vs. $\mathrm{H}_{2} \mathrm{O}_{2} . \mathrm{H}_{2} \mathrm{O}_{2}$, hydrogen peroxide treatment; CHOP, CCAAT-enhancer-binding protein homologous protein; R10/50/100, treatment with 10, 50 or $100 \mathrm{ng} / \mathrm{ml}$ relaxin-3, respectively.
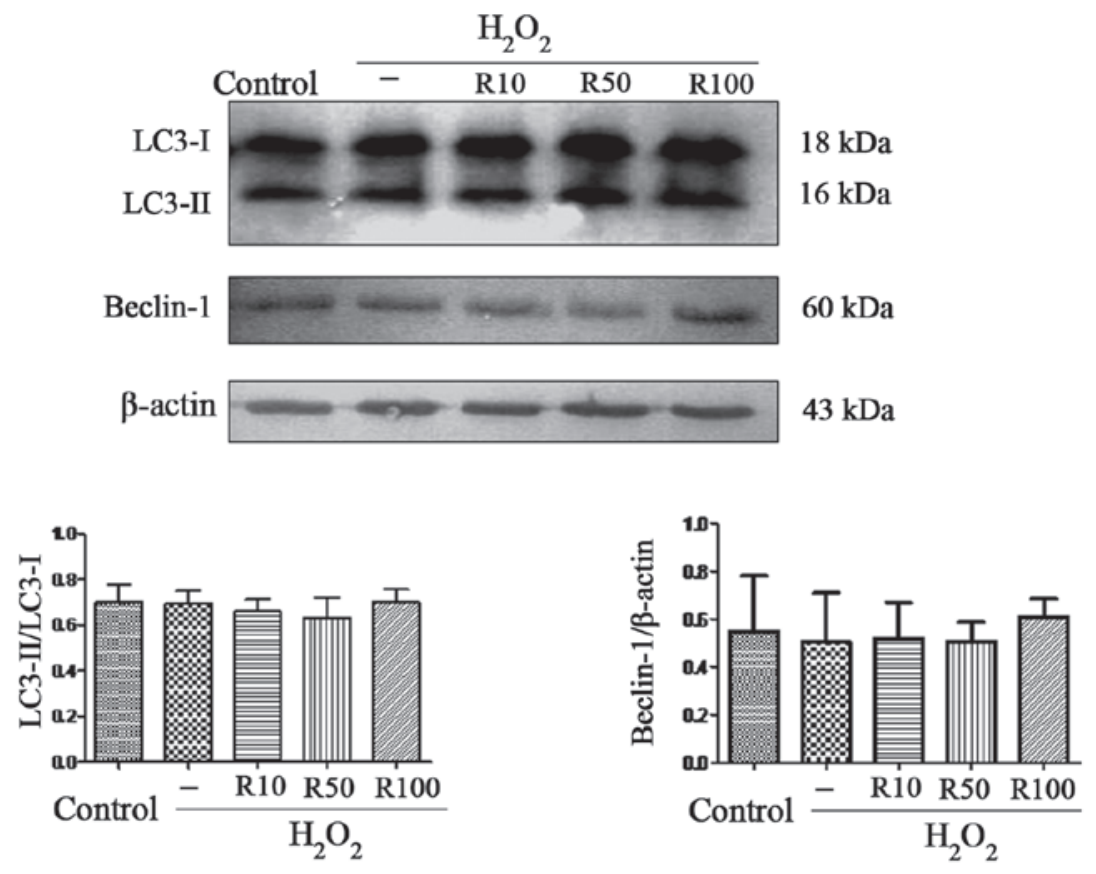

Figure 5. Expression of autophagy markers is unchanged following $\mathrm{H}_{2} \mathrm{O}_{2}$ treatment alone or in combination with relaxin-3. Western blot analysis of LC3-II/LC3-I and Beclin-1 protein expression in hepatocytes of the control, $\mathrm{H}_{2} \mathrm{O}_{2}$ or relaxin-3-treated ( $\mathrm{R} 10, \mathrm{R} 50$ and $\mathrm{R} 100$ for $24 \mathrm{~h}$ ) groups. $\beta$-actin was used as the internal control. Values are presented as the mean \pm standard deviation $(n=3) . \mathrm{H}_{2} \mathrm{O}_{2}$, hydrogen peroxide treatment; LC3, microtubule-associated protein 1 light chain 3; $\mathrm{R} 10 / 50 / 100$, treatment with 10,50 or $100 \mathrm{ng} / \mathrm{ml}$ relaxin-3, respectively.

expression levels of CHOP and cleaved caspase-12 in order to directly examine the role of relaxin-3 in ERS-associated apoptosis (Fig. 4). The results revealed elevated levels of CHOP and cleaved caspase- 12 in the $\mathrm{H}_{2} \mathrm{O}_{2}$ group. However, $10 \mu \mathrm{g} / \mathrm{ml}$ relaxin-3 treatment significantly inhibited the $\mathrm{H}_{2} \mathrm{O}_{2}$-induced overexpression of CHOP and cleaved caspase-12 $(\mathrm{P}<0.05)$, while this effect was not observed at higher doses of relaxin-3.
Relaxin-3 has no effect on markers of autophagy in apoptotic hepatocytes. Autophagy is the process by which cells recycle cytoplasm and degrade surplus or dysfunctional organelles (23). It has been reported that autophagy was the cell survival mechanism of primary human hepatocytes during oxidative stress (24). In order to examine the effect of relaxin-3 on autophagy in $\mathrm{H}_{2} \mathrm{O}_{2}$-induced hepatocyte apoptosis, the present study aimed to determine the expression levels of 
LC3-II/LC3-I and Beclin-1. The results showed that the expression of these autophagy markers was unchanged following $\mathrm{H}_{2} \mathrm{O}_{2}$ treatment alone or in combination with relaxin-3 treatment (Fig. 5).

\section{Discussion}

Relaxin-3, the 'ancestral' member of the relaxin peptide family, activates RXFP3 which is involved in stress and anxiety responses (25) as well as appetite regulation $(26,27)$, and whose expression is highest in the brain (28). However, the effect of relaxin-3 on other organs and tissues is has not been studied in detail (29). To the best of our knowledge, the present study was the first to demonstrate the impact of relaxin-3 on $\mathrm{H}_{2} \mathrm{O}_{2}$-induced hepatocyte apoptosis.

$\mathrm{H}_{2} \mathrm{O}_{2}$ is widely used as a model of oxidative stress in order to induce apoptosis. $\mathrm{H}_{2} \mathrm{O}_{2}$ stimulation induces enhances expression of ROS, which may exhaust hepatocellular antioxidant defenses, resulting in oxidative stress and hepatocyte apoptosis (30). In the present study, hepatocytes were incubated with $200 \mu \mathrm{mol} / 1 \mathrm{H}_{2} \mathrm{O}_{2}$ for $24 \mathrm{~h}$, as previously reported (31). Following treatment with relaxin-3 (10 ng/ml), a significant increase in cell viability was observed as well as a marked decrease in cleaved caspase-3 expression compared with levels in the untreated $\mathrm{H}_{2} \mathrm{O}_{2}$ group. In addition, Hoechst staining and electron microscopy revealed a decrease in the number of apoptotic hepatocytes. The results therefore indicated that relaxin-3 was involved in the protection of hepatocytes from pathological apoptosis.

The role of relaxin-3 in stress/anxiety and appetite regulation is currently defined by the regional distribution of RXFP3 in the brain, and relaxin-3 was also reported to bind to RXFP1, a relaxin-2 receptor, which is expressed primarily in the liver $(16,32)$. A previous study reported that relaxin-3 had an anti-fibrotic effect on cirrhotic liver tissue, which resulted in RXFR1 upregulation (18). In addition, the anti-apoptotic action of relaxin-2 in combination with RXFP1 was previously described in cardiac (20) and reproductive tissues (19,33). Based on evidence provided by these previous studies, it was hypothesized that relaxin-3 may attenuate hepatocyte apoptosis via the activation of RXFP1; however, further studies are required in order to characterize the role of RXFPs in apoptotic hepatocytes and determine the signaling properties of relaxin-3.

Of note, in the present study, the anti-apoptotic action of relaxin-3 did not proceed in a dose-dependent manner; by contrast, the low dose of relaxin-3 (10 ng/ml) produced significant results, indicative of its effectiveness in protecting hepatocytes from apoptosis, while higher concentrations of relaxin-3 (50 and $100 \mathrm{ng} / \mathrm{ml}$ ) were less effective and produced non-significant results in the majority of experiments performed. Further studies are required in order to elucidate the mechanisms underlying the effectiveness of low-dose relaxin-3 compared to that of higher doses.

Numerous studies have confirmed that caspases have a pivotal role in $\mathrm{H}_{2} \mathrm{O}_{2}$-induced apoptosis. There are two major pathways by which hepatocyte apoptosis is induced (34): The extrinsic (death receptor-mediated) pathway, which is initiated through the activation of caspase- 8 by death receptors followed by the caspase- 8 induced activation of an effector caspase (caspase-3); the intrinsic (mitochondrial apoptosis) pathway, which is initiated by the activation of caspase-9 following cytochrome c release from mitochondria, which in turn activates caspase-3. Previous studies have associated $\mathrm{H}_{2} \mathrm{O}_{2}$-mediated apoptosis with the intrinsic pathway of hepatocyte apoptosis $(30,35)$; however, the results of the present study demonstrated the significantly increased expression of cleaved caspase- 8 as well as caspase- 9 following hepatocyte treatment with $\mathrm{H}_{2} \mathrm{O}_{2}$. These results may be explained by the close interlinking of the two pathways, as the mitochondrial pathway may amplify the relatively weak death receptor-induced apoptotic signal in hepatocytes (36). Furthermore, relaxin-3 treatment was found to significantly decrease the expression of cleaved caspase- 8 and -9 , indicating that relaxin-3 prevented hepatocyte apoptosis via the inhibition of caspase- 8 and -9 activation.

The ER, analogous to mitochondria, directly initiates caspase activation and apoptotic pathways (10). A previous study reported that ERS was involved in $\mathrm{H}_{2} \mathrm{O}_{2}$-induced apoptosis in hepatocytes (37), which is consistent with the results of the present study, as levels of cleaved caspase-12 and CHOP were markedly increased following incubation with $\mathrm{H}_{2} \mathrm{O}_{2}$. In addition, relaxin-3 significantly reduced the overexpression of cleaved caspase-12 and CHOP, providing evidence for the attenuation of $\mathrm{H}_{2} \mathrm{O}_{2}$-induced hepatocyte apoptosis following relaxin-3 treatment via the inhibition of ERS.

Autophagy is an important mechanism by which cells maintain homeostasis; however, the precise role of autophagy within hepatocytes during liver disease and injury remains to be fully elucidated. A recent study reported that hepatocyte autophagy served as a cell survival mechanism for primary human hepatocytes under hypoxic stress (24). However, the results of the present study revealed that $\mathrm{H}_{2} \mathrm{O}_{2}$ and relaxin- 3 did not induce any obvious changes in the expression of hepatocyte autophagy markers. This therefore indicated that autophagy was not involved in the late stages of severe hepatocyte injury, which contradicts the results of a previous study, which reported that mild ischemia led to the induction of autophagy and apoptosis, while moderate/severe ischemia induced apoptotic and necrotic cell death without increasing autophagy (38). The morphological observations of the present study revealed that the $\mathrm{H}_{2} \mathrm{O}_{2}$-treated cells showed charateristics of the late stages of apoptosis; therefore suggesting that autophagy may not be the major mechanism mediating late-stage cell death in hepatocytes.

In conclusion, to the best of our knowledge, the present study provided the first evidence for the protective effect of relaxin-3 in hepatocytes following $\mathrm{H}_{2} \mathrm{O}_{2}$-induced apoptosis. Furthermore, the anti-apoptotic role of relaxin-3 was demonstrated to be mediated via decreased activation of upstream initiator caspases (caspase-8 and -9) and the inhibition of the ERS pathway.

\section{Acknowledgements}

The authors would like to thank Professors Donghui Li and Lovedip S. Kooner for their assistance in revising the manuscript.

\section{References}

1. Horvathova E, Eckl PM, Bresgen N and Slamenova D: Evaluation of genotoxic and cytotoxic effects of H2O2 and DMNQ on freshly isolated rat hepatocytes; protective effects of carboxymethyl chitin-glucan. Neuro Endocrinol Lett 29: 644-648, 2008. 
2. Miñana JB, Gómez-Cambronero L, Lloret A, et al: Mitochondrial oxidative stress and CD95 ligand: a dual mechanism for hepatocyte apoptosis in chronic alcoholism. Hepatology 35 1205-1214, 2002.

3. Jaeschke H, McGill MR and Ramachandran A: Oxidant stress, mitochondria, and cell death mechanisms in drug-induced liver injury: lessons learned from acetaminophen hepatotoxicity. Drug Metab Rev 44: 88-106, 2012.

4. Kundu D, Roy A, Mandal T, Bandyopadhyay U, Ghosh E and Ray D: Oxidative stress in alcoholic and viral hepatitis. N Am J Med Sci 4: 412-415, 2012.

5. Koike K: Oxidative stress and apoptosis in hepatitis C: the core issue. J Gastroenterol 41: 292-294, 2006.

6. Rodrigues CM, Fan G, Wong PY, Kren BT and Steer CJ: Ursodeoxycholic acid may inhibit deoxycholic acid-induced apoptosis by modulating mitochondrial transmembrane potential and reactive oxygen species production. Mol Med 4: 165-178, 1998

7. Canbay A, Gieseler RK, Gores GJ and Gerken G: The relationship between apoptosis and non-alcoholic fatty liver disease: an evolutionary cornerstone turned pathogenic. Z Gastroenterol 43 211-217, 2005

8. Canbay A, Friedman S and Gores GJ: Apoptosis: the nexus of liver injury and fibrosis. Hepatology 39: 273-278, 2004.

9. Matthews GM, Newbold A and Johnstone RW: Intrinsic and extrinsic apoptotic pathway signaling as determinants of histone deacetylase inhibitor antitumor activity. Adv Cancer Res 116: 165-197, 2012

10. Breckenridge DG, Germain M, Mathai JP, Nguyen M and Shore GC: Regulation of apoptosis by endoplasmic reticulum pathways. Oncogene 22: 8608-8618, 2003.

11. McCullough KD, Martindale JL, Klotz LO, Aw TY and Holbrook NJ: Gadd153 sensitizes cells to endoplasmic reticulum stress by down-regulating $\mathrm{Bcl} 2$ and perturbing the cellular redox state. Mol Cell Biol 21: 1249-1259, 2001.

12. Puthalakath H, O'Reilly LA, Gunn P, Lee L, et al: ER stress triggers apoptosis by activating BH3-only protein Bim. Cell 129: $1337-1349,2007$

13. Nakagawa T, Zhu H, Morishima N, Li E, Xu J, Yankner BA and Yuan J: Caspase-12 mediates endoplasmic-reticulum-specific apoptosis and cytotoxicity by amyloid-beta. Nature 403: 98-103, 2000.

14. Bathgate RA, Samuel CS, Burazin TC, et al: Human relaxin gene $3(\mathrm{H} 3)$ and the equivalent mouse relaxin (M3) gene: Novel members of the relaxin peptide family. J Biol Chem 277: $1148-1157,2002$

15. McGowan BM, Stanley SA, Ghatei MA and Bloom SR: Relaxin-3 and its role in neuroendocrine function. Ann NY Acad Sci 1160: 250-255, 2009.

16. Chan LJ, Hossain MA, Samuel CS, Separovic F and Wade JD The relaxin peptide family - structure, function and clinical applications. Protein Pept Lett 18: 220-229, 2011.

17. Fallowfield JA, Hayden AL, Snowdon VK, Aucott RL, Stutchfield BM, Mole DJ, Pellicoro A, Gordon-Walker TT, Henke A, Schrader J, Trivedi PJ, Princivalle M, Forbes SJ, Collins JE and Iredale JP: Relaxin modulates human and rat hepatic myofibroblast function and ameliorates portal hypertension in vivo. Hepatology 59: 1492-1504, 2014.

18. Bennett RG, Dalton SR, Mahan KJ, Gentry-Nielsen MJ, Hamel FG and Tuma DJ: Relaxin receptors in hepatic stellate cells and cirrhotic liver. Biochem Pharmacol 73: 1033-1040, 2007.

19. Yao L, Agoulnik AI, Cooke PS, Meling DD and Sherwood OD Relaxin acts on stromal cells to promote epithelial and stromal proliferation and inhibit apoptosis in the mouse cervix and vagina. Endocrinology 149: 2072-2079, 2008.
20. Moore XL, Tan SL, Lo CY, et al: Relaxin antagonizes hypertrophy and apoptosis in neonatal rat cardiomyocytes. Endocrinology 148: 1582-1589. 2007.

21. Wu CC and Bratton SB: Regulation of the intrinsic apoptosis pathway by reactive oxygen species. Antioxid Redox Signal 19: 546-558, 2013.

22. Shore GC, Papa FR and Oakes SA: Signaling cell death from the endoplasmic reticulum stress response. Curr Opin Cell Biol 23: 143-149, 2011.

23. Ryter SW, Cloonan SM and Choi AM: Autophagy: a critical regulator of cellular metabolism and homeostasis. Mol Cells 36 7-16, 2013.

24. Bhogal RH, Weston CJ, Curbishley SM, Adams DH and Afford SC: Autophagy: a cyto-protective mechanism which prevents primary human hepatocyte apoptosis during oxidative stress. Autophagy 8: 545-558, 2012.

25. Tanaka M, Iijima N, Miyamoto Y, Fukusumi S, Itoh Y, Ozawa $\mathrm{H}$ and Ibata Y: Neurons expressing relaxin 3/INSL 7 in the nucleus incertus respond to stress. Eur J Neurosci 21: 1659-1670, 2005.

26. McGowan BM, Stanley SA, Smith KL, et al: Central relaxin-3 administration causes hyperphagia in male Wistar rats. Endocrinology 146: 3295-3300, 2005.

27. Hida T, Takahashi E, Shikata K, et al: Chronic intracerebroventricular administration of relaxin-3 increases body weight in rats. J Recept Signal Transduct Res 26: 147-158, 2006.

28. Sutton SW, Bonaventure P, Kuei C, Roland B, Chen J, Nepomuceno D, Lovenberg TW and Liu C: Distribution of G-protein-coupled receptor (GPCR)135 binding sites and receptor mRNA in the rat brain suggests a role for relaxin-3 in neuroendocrine and sensory processing. Neuroendocrinology 80 : 298-307, 2004

29. Smith CM, Ryan PJ, Hosken IT, Ma S and Gundlach AL: Relaxin-3 systems in the brain - the first 10 years. J Chem Neuroanat 42: 262-275, 2011.

30. Czaja MJ: Induction and regulation of hepatocyte apoptosis by oxidative stress. Antioxid Redox Signal 4: 759-767, 2002.

31. Wang H, Xue Z, Wang Q, Feng X and Shen Z: Propofol protects hepatic L02 cells from hydrogen peroxide-induced apoptosis via activation of extracellular signal-regulated kinases pathway. Anesth Analg 107: 534-540, 2008.

32. van der Westhuizen ET, Halls ML, Samuel CS, Bathgate RA, Unemori EN, Sutton SW and Summers RJ: Relaxin family peptide receptors - from orphans to therapeutic targets. Drug Discov Today 13: 640-651, 2008

33. Zhao S, Fields PA and Sherwood OD: Evidence that relaxin inhibits apoptosis in the cervix and the vagina during the second half of pregnancy in the rat. Endocrinology 142: 2221-2229, 2001.

34. Ghavami S, Hashemi M, Kadkhoda K, Alavian SM, Bay GH and Los M: Apoptosis in liver diseases - detection and therapeutic applications. Med Sci Monit 11: RA337-RA345, 2005.

35. Kannan $\mathrm{K}$ and Jain SK: Oxidative stress and apoptosis. Pathophysiology 7: 153-163, 2000.

36. Yin XM and Ding WX: Death receptor activation-induced hepatocyte apoptosis and liver injury. Curr Mol Med 3: 491-508, 2003.

37. Liu YY, Xie Q, Wang H, Lin LY, Jiang S, Zhou XQ, Yu H and Guo Q: The effect of $N$-acetyl-L-cysteine on endoplasmic reticulum stress mediated apoptosis of HepG2 cells. Zhonghua Gan Zang Bing Za Zhi 16: 524-527, 2008 (In Chinese).

38. Loos B, Genade S, Ellis B, Lochner A and Engelbrecht AM: At the core of survival: autophagy delays the onset of both apoptotic and necrotic cell death in a model of ischemic cell injury. Exp Cell Res 317: 1437-1453, 2011. 